\title{
PREVENTION OF CELLULAR EDEMA DIRECTLY CAUSED BY HYPOTHERMIC CARDIOPLEGIA: STUDIES IN ISOLATED HUMAN AND RABBIT ATRIAL MYOCYTES
}

Robert F. Shaffer, MS

Clive M. Baumgarten, $\mathrm{PhD}^{\mathrm{a}}$

Ralph J. Damiano, Jr., MD ${ }^{\mathrm{b}, \mathrm{c}}$
Objectives: This study tested the hypothesis that edema during hypothermic cardioplegia is caused by the hypotonicity of the perfusate at cold temperatures. Methods: The volume of isolated human and rabbit atrial myocytes was measured by video microscopy under nonischemic conditions. Each cell served as its own control. Results: After equilibration in $37^{\circ} \mathrm{C}$ physiologic buffer (Tyrode's solution), exposure to $9^{\circ} \mathrm{C}$ St. Thomas' Hospital solution for 20 minutes caused human atrial cells to swell by $20 \%$ and rabbit atrial cells to swell by $10 \%$. Cell volume fully recovered on rewarming in $37^{\circ} \mathrm{C}$ physiologic solution. Cell swelling was due to the composition of St. Thomas' Hospital solution rather than hypothermia alone. Exposure to $9^{\circ} \mathrm{C}$ physiologic solution did not significantly affect cell volume. Swelling of myocytes was largely prevented by replacing most of the $\mathrm{Cl}^{-}$in St. Thomas' Hospital solution with an impermeant anion so that the product of the concentrations of $\mathrm{K}^{+}$and $\mathrm{Cl}^{-}$were the same as in the physiologic solution. Conclusions: This study suggests that cell swelling during hypothermic cardioplegia is caused in part by the composition of the cardioplegic solution. The volume of cardiac myocytes appears to follow a Donnan equilibrium in the cold, and the perfusate $\mathrm{KCl}$ product determines water movement. Thus, the tonicity of hyperkalemic cardioplegic solutions can be adjusted to a physiologic value by replacing most $\mathrm{Cl}^{-}$by an impermeant anion. Following this simple principle, a reformulation of cardioplegic solutions may be able to minimize iatrogenic myocardial edema. (J Thorac Cardiovasc Surg 1998;115:1189-95)
$\mathrm{H}^{\mathrm{s}}$ ypothermic hyperkalemic cardioplegia is the cornerstone of most strategies for arresting and protecting the myocardium during operative intervention. ${ }^{1}$ However, cardioplegic arrest can lead to significant postoperative abnormalities. Metabolic intermediates and mitochondrial respiration are disturbed, ${ }^{2-4}$ left ventricular function is depressed, ${ }^{2,5-8}$ and rhythm and conduction abnormalities are prev-

From the Departments of Physiology a and Surgery, ${ }^{\mathrm{b}}$ Medical College of Virginia, Virginia Commonwealth University, Richmond, Va., and the Division of Cardiothoracic Surgery, ${ }^{c}$ Pennsylvania State University, Hershey, Pa.

Supported by National Institutes of Health grants HL-46764 and HL-51032.

Received for publication April 10, 1997; revisions requested May 14, 1997; revisions received Dec. 10, 1997; accepted for publication Dec. 22, 1997.

Address for reprints: Ralph J. Damiano, Jr., MD, Division of Cardiothoracic Surgery, Pennsylvania State University, P.O. Box 850, Hershey, PA 17033-0850.

Copyright (C) 1998 by Mosby, Inc.

$0022-5223 / 98 \$ 5.00+0 \quad \mathbf{1 2 / 1 / 8 8 6 8 9}$ alent. ${ }^{9,} 10$ Myocardial water content increases ${ }^{4-8,11}$ and cellular swelling is observed with both crystalloid and blood cardioplegia. ${ }^{12,13}$ Cellular edema is thought to contribute to the observed mechanical dysfunction, ${ }^{6-8}$ slowed conduction and arrhythmogenesis, ${ }^{10}$ and decreased coronary flow on reperfusion. $^{8,14,15}$

It has long been assumed that the cellular edema associated with cardioplegia is induced by ischemia or inhibition of the $\mathrm{Na}^{+}-\mathrm{K}^{+}$pump by hypothermia. ${ }^{1}$ An additional mechanism may be a direct consequence of the composition of the isosmotic cardioplegic solution. A solution may be isosmotic with plasma but still induce myocardial cell swelling if it is hypotonic. Osmolarity is a property of the solution alone, whereas tonicity depends on properties of both the solution and membrane and can be dependent on temperature. ${ }^{16}$ Previously, we demonstrated that cold St. Thomas' Hospital solution is hypotonic for rabbit ventricular myocytes and induces cell swelling in the absence of ischemic injury. ${ }^{17}$ The situation for human myocytes remains unclear, how- 

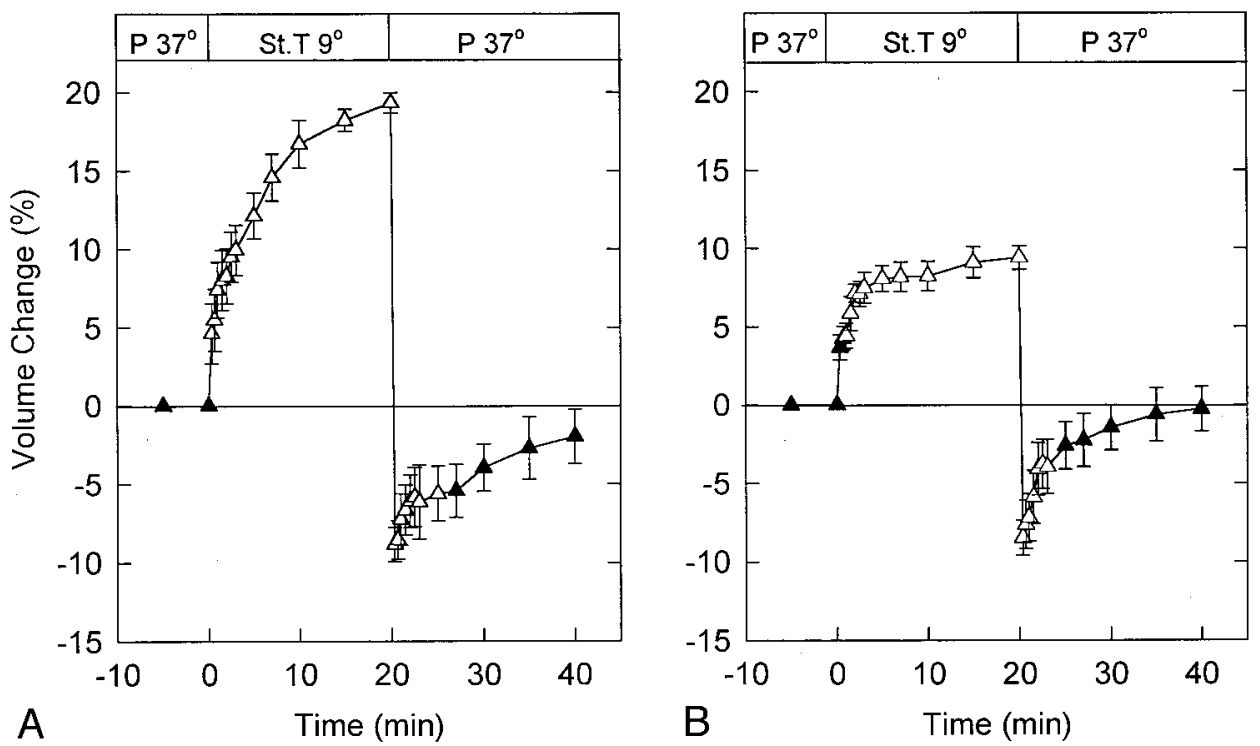

Fig. 1. Relative cell volume of (A) human atrial myocytes $(n=6)$ and (B) rabbit atrial myocytes during 20 minutes in $9^{\circ} \mathrm{C}$ St. Thomas' Hospital solution (St. T.) and 20 minutes of rewarming in $37^{\circ} \mathrm{C}$ physiologic solution (Tyrode's solution). Cell volume is expressed relative to that under control conditions. Unfilled symbols represent a statistically significant change from control $(p<0.05)$. A, Human cells rapidly swelled on exposure to cold St. Thomas' Hospital solution. Volume transiently decreased below the control level on rewarming. B, Rabbit cells rapidly swelled on exposure to cold St. Thomas' Hospital solution. Volume transiently decreased on rewarming. Cell swelling in human atrial myocytes (A) was significantly greater than that in rabbit atrial myocytes (B). P, Physiologic solution.

ever, because cell volume regulation is speciesdependent. ${ }^{16,18}$ Our experiments were designed to determine whether hypothermic St. Thomas' Hospital cardioplegic solution caused human atrial myocytes to swell in the absence of ischemic injury. Parallel studies were conducted on rabbit atrial myocytes.

\section{Materials and methods}

Isolation of myocytes. Both human and rabbit atrial myocytes were studied. Rabbits (New Zealand White, 1.5 to $3.0 \mathrm{~kg}$, either sex) were humanely put to death with anesthesia (acepromazine maleate [INN: acepromazine], $25 \mathrm{mg} / \mathrm{kg}$; rompum, $5 \mathrm{mg} / \mathrm{kg}$; ketamine, $50 \mathrm{mg} / \mathrm{kg}$ ), and the right atria were removed. Human right atrial tissue was obtained in accordance with a protocol approved by the Committee on the Conduct of Human Research at the Medical College of Virginia, Virginia Commonwealth University, from 14 patients undergoing cardiac operation. Right atrial tissue was used because of the ease of availability compared with ventricular tissue. Samples were taken from the tip of the right atrial appendage immediately before cannulation to establish extracorporeal circulation. All patients were undergoing coronary artery bypass grafting; the cases represented randomly selected men and women ranging in age from 44 to 70 years. All cardioactive drugs were stopped 12 hours before operation. The perioperative drugs given were consistent among all patient groups and included heparin, 300 $\mathrm{IU} / \mathrm{mg}$, vancomycin, $1 \mathrm{gm}$ intravenously, and routine anesthetic agents. Human tissue samples and isolated myocytes were considered potentially infectious and were handled accordingly.

Human and rabbit myocytes were isolated using a technique modified from methods previously described. ${ }^{19-21}$ The tissue samples, ranging in size from 5 to $10 \mathrm{~mm}$, were placed in a room temperature flask containing an oxygenated HEPES buffered solution containing (in millimoles per liter): $120 \mathrm{NaCl}, 5.4 \mathrm{KCl}, 0.5 \mathrm{MgSO}_{4}$, 5.0 sodium pyruvate, 20 glucose, 20 taurine, 30 2,3butanedione monoxime (BDM), 10 HEPES buffer, and 6 nitrilotriacetic acid (NTA) and was titrated to $\mathrm{pH} 7.3$ with $\mathrm{NaOH}$. Human tissue was transported to the laboratory for processing within 10 minutes of excision and was placed in a Petri dish containing the same $\mathrm{Ca}^{2+}$-free HEPES-buffered solution used for transport but without NTA. The tissue was rinsed vigorously for 2 minutes and was sliced into 1 to $3 \mathrm{~mm}$ pieces using a sterile No. 10 scalpel blade.

Tissue slices were placed in a $25 \mathrm{ml}$ Erlenmeyer flask in a $37^{\circ} \mathrm{C}$ reciprocating shaker bath (model 25; Precision Scientific, Chicago, Ill.) and were dissociated into isolated myocytes in HEPES-buffered solution modified by the addition of enzymes and $50 \mu \mathrm{mol} / \mathrm{L} \mathrm{CaCl}_{2}$ and the omis- 

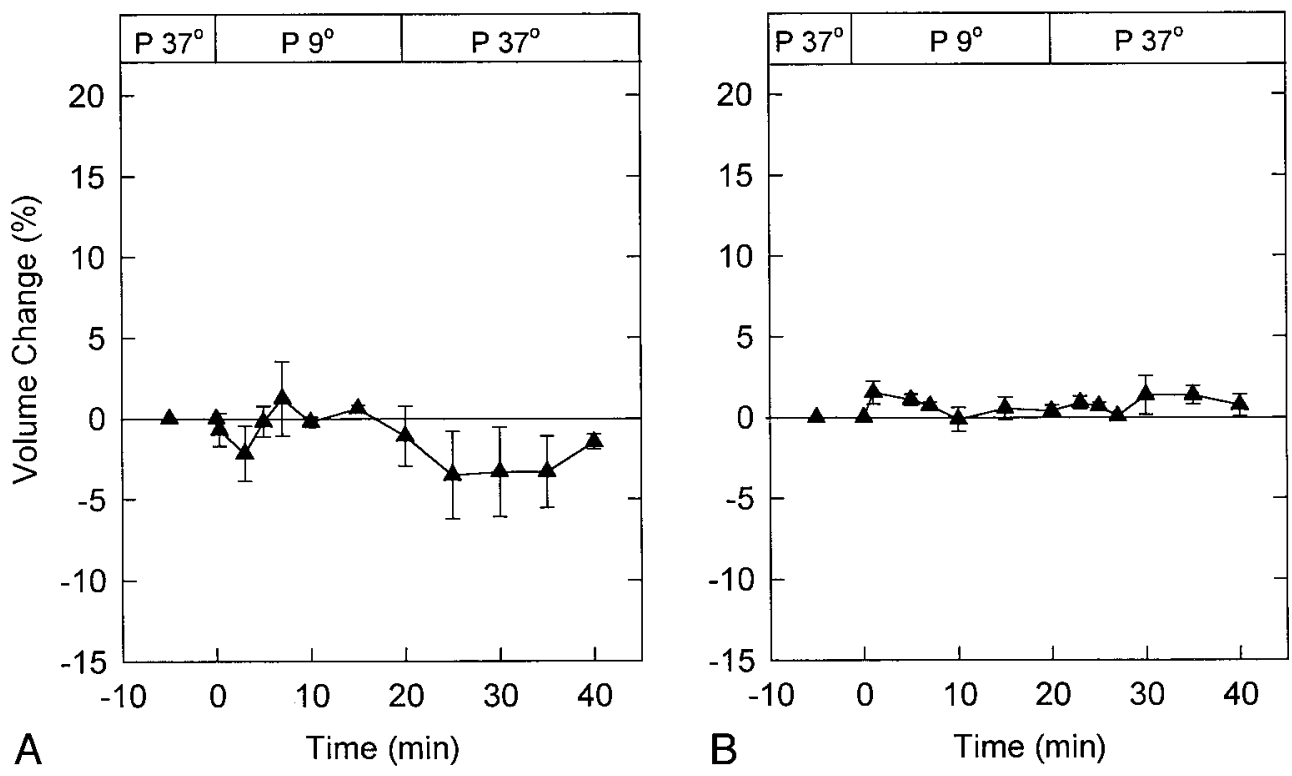

Fig. 2. Relative cell volume of (A) human atrial myocytes $(n=4)$ and (B) rabbit atrial myocytes $(n=4)$ during 20 minutes in $9^{\circ} \mathrm{C}$ physiologic solution and 20 minutes of rewarming at $37^{\circ} \mathrm{C}$ in the same solution. Hypothermia in physiologic solution did not significantly affect either human or rabbit atrial cell volume. $P$, Physiologic solution.

sion of NTA. A three-step procedure was used: (1) protease, type XXIV (Sigma Chemical, St. Louis, Mo.), 4 $\mathrm{U} / \mathrm{ml}$ for 15 minutes; (2) collagenase A (Boehringer Mannheim, Indianapolis, Ind.), $1 \mathrm{mg} / \mathrm{ml}$, and hyaluronidase (Sigma), $0.5 \mathrm{mg} / \mathrm{ml}$, for 20 minutes; (3) collagenase A, $1.5 \mathrm{mg} / \mathrm{ml}$, alone for one or two 20 -minute cycles. The isolate was filtered through a $250 \mathrm{Fm}$ nylon mesh to remove debris, and myocytes were gently centrifuged and washed three times in HEPES-buffered solution containing $30 \mathrm{mmol} / \mathrm{L} \mathrm{BDM}$ and $250 \mathrm{Fm} \mathrm{Ca}^{2+}$. Cells were stored in this solution at room temperature until used for imaging.

Imaging. An aliquot of myocytes was placed in a polyL-lysine-coated chamber and allowed to settle for 5 minutes. Then the chamber was perfused with $37^{\circ} \mathrm{C}$ physiologic buffer solution at a flow rate of $5 \mathrm{ml} / \mathrm{min}$. The physiologic (modified Tyrode's) solution contained (in millimoles per liter): $130 \mathrm{NaCl}, 5 \mathrm{KCl}, 2.5 \mathrm{CaCl}_{2}, 1.75$ $\mathrm{NaH}_{2} \mathrm{PO}_{4}, 1.2 \mathrm{MgSO}_{4}$, and $24 \mathrm{NaHCO}_{3}$ and was equilibrated with $95 \%$ oxygen and $5 \%$ carbon dioxide and titrated to $\mathrm{pH} 7.4$ with $\mathrm{NaOH}$.

Myocytes were placed in a custom-made well for the entire perfusion period. Cells were constantly perfused at 4 to $5 \mathrm{ml} / \mathrm{min}$. Cooling and rewarming occurred rapidly over a 30- to 45-second period. The cold and warm solutions were separately maintained, and perfusion was changed by turning a three-way stopcock. Viable cells were chosen by several morphologic criteria, including sharp borders, no vacuoles in the cytoplasm, clear and distinct striations, and normal rod shape. If cells showed any evidence of contraction, they were excluded from the study.
Cell images were displayed on a video monitor (VM1220, Hitachi Denshi, Tokyo, Japan) by a high-resolution CCD camera (HP-101A, Hitachi) mounted on an inverted microscope (Diavery, Leitz, Wetzlar, Germany) equipped with Hoffman modulation optics (Modulation Optics, Greenvale, N.Y.). Hoffman optics were chosen to enhance contrast without the "halo" that surrounds cells viewed with phase contrast. The total magnification of the videooptical system, determined with a stage micrometer, was $\times 1912$ with a $\times 40$ objective. Usually, only a single myocyte was visible at one time.

Cell volumes were measured by methods developed in this laboratory. ${ }^{17,22,23}$ Images of the myocytes were captured using custom software and a video-frame grabber (Targa 16/32, Truevision, Santa Clara, Calif.) in a Pentium computer. The resolution of the digitization was 0.2 $\mu \mathrm{m} /$ pixel. The borders of the cell images were traced using JAVA image analysis software (Jandel Scientific, San Rafael, Calif.). JAVA provided contrast enhancement, image magnification, and an edge-tracing function that identified the borders of the cell with operator assistance. Relative cell volume was estimated by use of a custom program written in ASYST (Keithley Asyst, Tauton, Mass.).

Changes in the width and thickness of isolated myocytes in test solutions are proportional. ${ }^{22}$ Therefore, relative cell volume was determined as:

Volume $_{\text {test }} /$ volume $_{\text {control }}=\left(\right.$ Area $_{\text {test }} \times$ width $\left._{\text {test }}\right) /$

$$
\left(\text { Area }_{\text {control }} \times \text { width }_{\text {control }}\right)
$$



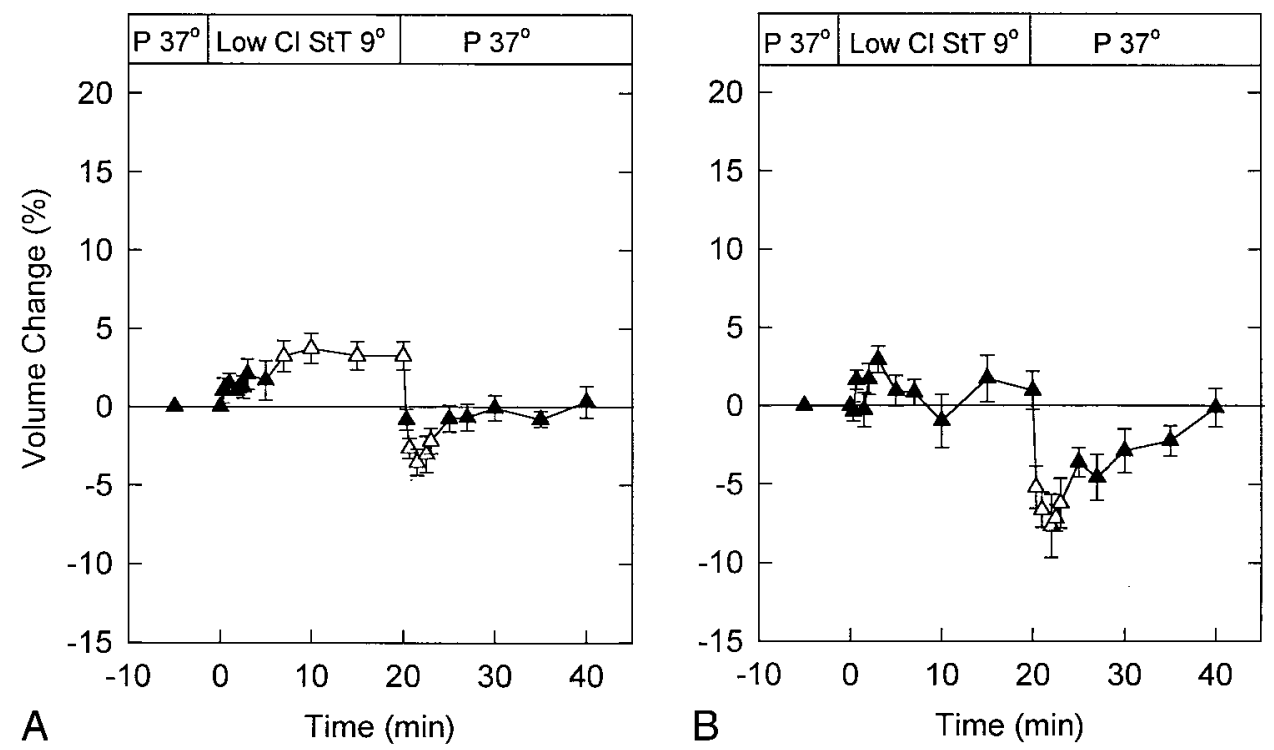

Fig. 3. Relative cell volume of (A) human atrial myocytes $(n=4)$ and (B) rabbit atrial myocytes $(n=4)$ during 20 minutes in $9^{\circ} \mathrm{C}_{\text {low } \mathrm{Cl}^{-}}(43.75 \mathrm{mmol} / \mathrm{L})$ St. Thomas' Hospital solution (St. T.) and 20 minutes of rewarming in $37^{\circ} \mathrm{C}$ physiologic solution (Tyrode's solution). The $\mathrm{KCl}$ product of low $\mathrm{Cl}^{-}$St. Thomas' Hospital solution was the same as that of physiologic solution. Unfilled data symbols represent a significant change from control $(p<0.05)$. $P$, Physiologic solution.

On the basis of repeated measurements of single images and measurements of multiple images, estimates of cell volume have been shown to be reproducible to less than $1 \% .^{17,22,23}$

Experimental protocol. Cells were perfused for $20 \mathrm{~min}$ utes in $37^{\circ} \mathrm{C}$ Tyrode's solution, a physiologic buffer, to establish baseline cell volumes. Cells were then perfused with $9^{\circ} \mathrm{C}$ Tyrode's solution or St. Thomas' Hospital solution for 20 minutes. The cell was then reperfused for 20 minutes in warm $37^{\circ} \mathrm{C}$ Tyrode's solution. Cell volume was measured every 1 to 5 minutes throughout the entire study. St. Thomas' Hospital solution contained (in millimoles per liter): $110 \mathrm{NaCl}, 10 \mathrm{NaHCO}_{3}, 16 \mathrm{KCl}, 16$ $\mathrm{MgCl}_{2}$, and $1.2 \mathrm{CaCl}_{2}$. The fact that St. Thomas' Hospital solution is hyperkalemic with a near normal $\mathrm{Cl}^{-}$concentration may explain the cause of cellular edema. Under hypothermic conditions, passive fluxes of ions modulate cell volume in accord with a Donnan equilibrium. ${ }^{16}$ In a Donnan equilibrium system, the membrane potential $\left(E_{m}\right)$ and the Nernst equilibrium potentials for $\mathrm{K}^{+}$and $\mathrm{Cl}^{-}$are equal. Writing this relationship and simplifying gives:

$$
\begin{aligned}
& \mathrm{E}_{\mathrm{m}}=-(\mathrm{RT} / \mathrm{F}) \ln \left(\left[\mathrm{K}^{+}\right]_{\mathrm{i}} /\left[\mathrm{K}^{+}\right]_{\mathrm{o}}\right) \\
&-(\mathrm{RT} / \mathrm{F}) \ln \left(\left[\mathrm{CI}^{-}\right]_{\mathrm{o}} /\left[\mathrm{CI}^{-}\right]_{\mathrm{i}}\right) \\
& \quad\left[\mathrm{K}^{+}\right]_{\mathrm{o}} \times\left[\mathrm{Cl}^{-}\right]_{\mathrm{o}}=\left[\mathrm{K}^{+}\right]_{\mathrm{I}} \times\left[\mathrm{Cl}^{-}\right]_{\mathrm{I}}
\end{aligned}
$$

where the bracketed chemical symbols refer to intracellular, $I$, and extracellular, $o$, concentrations, $R$ is the gas constant, $T$ is the temperature $\left({ }^{\circ} \mathrm{K}\right)$, and $F$ is Faraday's constant. As a consequence of these relationships, increasing the $\mathrm{KCl}$ product of the extracellular solution leads to an accumulation of $\mathrm{K}^{+}$and $\mathrm{Cl}^{-}$within the cell, and water follows osmotically. St. Thomas' Hospital solution has a much greater $\mathrm{KCl}$ product, $2566.4 \mathrm{mmol} / \mathrm{L}^{2}$, than either blood plasma (350 to $\left.550 \mathrm{mmol} / \mathrm{L}^{2}\right)$ or the control physiologic solution used here $\left(700 \mathrm{mmol} / \mathrm{L}^{2}\right)$. Thus Donnan equilibrium predicts cellular edema will result on exposure to St. Thomas' Hospital solution. To test whether the high $\mathrm{KCl}$ product of St. Thomas' Hospital solution was responsible for cell swelling, methanesulfonate, a large poorly permeant anion, was substituted for part of the $\mathrm{Cl}^{-}$in St. Thomas' Hospital solution. The $\mathrm{KCl}$ product of the modified low $\mathrm{Cl}^{-}$St. Thomas' Hospital solution was equal to that of the physiologic buffer.

Statistics. Data are reported as mean \pm standard error, and all statistical calculations were done with SigmaStat (Jandel). Analysis of variance used a repeated measures design. Because the variance tended to vary with the treatment mean, a logarithmic transform was applied to the data before analysis; the variance of the transformed data was more appropriate for the analytical model. Comparisons of treatment means to a control was done using Dunnett's procedure. In cases in which only a single comparison was used, Student's $t$ test was used.

\section{Results}

Under control conditions, the dimensions of human atrial cells were: width, $18.1 \pm 1.3 \mu \mathrm{m}$; length, $131.1 \pm 5.1 \mu \mathrm{m}$; volume, $38.9 \pm 7.3 \mathrm{pl}(n=14)$; 
rabbit atrial cells were: width, $16.6 \pm 1.3 \mu \mathrm{m}$; length, $107.9 \pm 7.3 \mu \mathrm{m}$; volume, $33.0 \pm 6.8 \mathrm{pl}(n=14)$. These calculations of volume made the assumption that cells were brick-shaped with equal thickness and width. If the cross-section was cylindric, the absolute cell volumes were overestimated by a factor of $4 / \pi, 1.27$. To avoid this uncertainty in the remaining results, cell volumes were expressed relative to that in control solution.

The effect of St. Thomas' Hospital solution on relative cell volume. Human atrial myocytes rapidly swelled when perfused with St. Thomas' Hospital solution $(n=6)$ (Fig. $1, A)$. The swelling reached statistical significance within 20 seconds, and relative cell volume increased by $12.1 \% \pm 1.5 \%$ and $19.3 \% \pm 0.6 \%$ after 5 and 20 minutes, respectively. Half of the volume increase occurred within the initial 3.6 \pm 1.5 minutes in cold St. Thomas' Hospital solution. The observed volume changes were a result of a change in the width of the cell; cell length stayed the same as in the control solution.

On rewarming in $37^{\circ} \mathrm{C}$ physiologic buffer, cell volume rapidly decreased to a value $8.8 \% \pm 1.1 \%$ $(p<0.009)$ less than the control volume. This shrinkage was transient. The half-time for recovery was $7.4 \pm 2.3$ minutes, and after 20 minutes, relative cell volume was $2.0 \% \pm 1.7 \%$ less than control.

Because previous work on the effect of cardioplegia on the volume of isolated myocytes was done using rabbit ventricular cells, ${ }^{22}$ we also studied rabbit atrial myocytes to examine whether the effect of cardioplegic solutions was tissue-specific (atrial vs ventricular) or species-specific (human vs rabbit). Rabbit atrial myocytes also rapidly swelled during the exposure to $9^{\circ} \mathrm{C}$ St. Thomas' Hospital solution $(n=6)$ (Fig. 1, B). The swelling was statistically significant within 40 seconds of exposure to cold cardioplegia, and relative cell volume increased by $8.1 \% \pm 0.8 \%$ and $9.4 \% \pm 0.8 \%$ after 5 and 20 minutes, respectively. The swelling of rabbit atrial myocytes was only about half that of human atrial myocytes $(p=0.0001)$. In contrast, rabbit atrial cell swelling was nearly identical to the swelling previously reported for rabbit ventricular cells in hypothermic St. Thomas' Hospital solution, 9.2\%. ${ }^{17}$ The differences in swelling between human and rabbit atrial cells may reflect a true species difference or the effects of in vivo disease processes.

When rabbit atrial cells were rewarmed in physiologic solution, relative cell volume decreased rapidly and transiently fell below baseline by $8.4 \% \pm$ $1.1 \%$. The half-time for recovery from shrinkage was $1.0 \pm 0.3$ minutes, significantly faster than for human cells $(p=0.015)$.

The hypotonicity and resulting cell swelling could be due to hypothermia itself or to the composition of St. Thomas' Hospital solution. To distinguish between these two possibilities, isolated myocytes were cooled to $9^{\circ} \mathrm{C}$ and rewarmed to $37^{\circ} \mathrm{C}$ in the same physiologic solution to test the effect of temperature alone. Experiments on both human (Fig. 2, $A$ ) and rabbit (Fig. 2, B) myocytes revealed that cell volume was not significantly affected during exposure to cold physiologic buffer solution or during subsequent rewarming.

Prevention of edema in cold St. Thomas' Hospital solution. The swelling of both human and rabbit atrial myocytes was markedly reduced with cold low $\mathrm{Cl}^{-}$St. Thomas' Hospital solution. For human atrial cells the maximum swelling in cold low $\mathrm{Cl}^{-}$St. Thomas' Hospital solution was $3.7 \% \pm 1.0 \%(n=$ 4), (Fig. 3, $A$ ), only one fifth as much as the $19.3 \%$ swelling in standard St. Thomas' Hospital solution (Fig. 1, A). Nevertheless, swelling of human atrial myocytes remained statistically significant with respect to control after 7 minutes in low $\mathrm{Cl}^{-}$St. Thomas' Hospital solution. In contrast, rabbit atrial cells did not significantly swell during a 20-minute exposure to low $\mathrm{Cl}^{-}$St. Thomas' Hospital solution (Fig. 3, B). On rewarming, both human and rabbit myocytes that had been exposed to low $\mathrm{Cl}^{-}$St. Thomas' Hospital solution transiently shrank to less than their control volumes $(3.5 \% \pm 0.8 \%$ and $7.6 \%$ $\pm 2.0 \%$, respectively) (Fig. $3, A$ ). However, after 20 minutes of recovery in warm physiologic solution, both had returned to their baseline volumes.

\section{Discussion}

Physiologic basis for cardioplegia-induced cellular edema. Although cardioplegia is intended to protect the myocardium during elective cardiac arrest, ${ }^{1}$ this study demonstrated that $9^{\circ} \mathrm{C}$ St. Thomas' Hospital solution rapidly induced cellular edema in the absence of ischemia in both human and rabbit atrial myocytes. The composition of St. Thomas' Hospital solution was found to be critical to the development of edema. Cell swelling was absent or markedly reduced during hypothermia in a low $\mathrm{Cl}^{-}$ (43.75 mmol/L) St. Thomas' Hospital solution or in a physiologic solution. The simplest explanation for these data is that cardiac cells behave as a Donnan equilibrium system in the cold. This means that altering the extracellular $\mathrm{KCl}$ product will cause a redistribution of intracellular $\mathrm{K}^{+}$and $\mathrm{Cl}^{-}$, and water 
will follow affecting cell volume. ${ }^{16}$ It is unlikely that myocyte swelling was due to the choice of crystalloid solution rather than blood as a vehicle for delivery. Previous work has shown that isolated myocytes swell in both blood and crystalloid cardioplegic solutions. ${ }^{13}$

Although these data strongly suggest that the $\mathrm{KCl}$ product is an important factor, they are not conclusive in this regard. Further studies are necessary to clarify this issue, including the investigation of cardioplegic solutions of various $\mathrm{KCl}$ products. This would help clarify whether the effect of sodium methanesulfonate is dependent on the $\mathrm{Cl}^{-}$concentration. The effect of sodium methanesulfonate itself needs to be examined by studying whether other impermeant anions have a similar effect.

It has been suggested previously that inhibition of the $\mathrm{Na}^{+}-\mathrm{K}^{+}$pump by hypothermia might lead to cell swelling during cardioplegia in the absence of ischemia. ${ }^{1,24}$ Each cycle of the $\mathrm{Na}^{+}-\mathrm{K}^{+}$pump extrudes $3 \mathrm{Na}^{+}$while taking up $2 \mathrm{~K}^{+}$, a net efflux of osmotically active particles. As $\mathrm{Na}^{+}$passively enters the cell, pump inhibition allows the accumulation of $\mathrm{Na}^{+}$and thus water. However, in this study inhibition of the $\mathrm{Na}^{+}-\mathrm{K}^{+}$pump by hypothermia was not sufficient to cause atrial myocyte swelling. Ventricular myocyte volume and cell water also have been shown to be resistant to $\mathrm{Na}^{+}-\mathrm{K}^{+}$pump inhibition. ${ }^{25,}{ }^{26}$ Failure to swell despite pump inhibition is consistent with the view that the leak of $\mathrm{Na}^{+}$into quiescent cardiac cells is small. On the other hand, depolarization to near $-50 \mathrm{mV}$, as occurs during hyperkalemic arrest, increases $\mathrm{Na}^{+}$influx and elevates the cytoplasmic $\left[\mathrm{Na}^{+}\right] .{ }^{24}$ This may explain the more severe swelling of atrial cells in St. Thomas' Hospital solution and explain why low $\mathrm{Cl}^{-}$St. Thomas' Hospital solution failed to fully abolish their swelling. Alternatively, human atrial cells may be more permeant to methanesulfonate, the $\mathrm{Cl}^{-}$ replacement, than rabbit myocytes.

Limitations. Studying isolated myocytes has the great advantage of permitting direct measurement of cell volume over time in the absence of ischemia. However, several factors must be considered before applying the conclusions drawn here to clinical situations. Isolated myocytes in flowing solution do not reflect the effects of the complex geometry of the arrested heart wherein extracellular volume is limited. Cellular edema during cardioplegic arrest of intact hearts initially results from a fluid transfer from the interstitial to the cellular compartment. ${ }^{27}$ Later, interstitial edema can develop as fluid moves in from the vascular compartment. On reperfusion, washout of the extracellular spaces creates an osmotic gradient favoring further cell swelling and, in severe cases, rupture of the cell membrane. ${ }^{28}$ Moreover, the role of vascular, neural, and interstitial elements was ignored. The high $\mathrm{K}^{+}$in cardioplegic solutions may directly damage vascular endothelium. ${ }^{29}$ Also, myocardial cellular edema increases coronary vascular resistance and can limit or prevent effective reperfusion. ${ }^{14,15}$ Thus, the present investigation only considered one of the many factors contributing to cellular edema and cardiac dysfunction. This study also involved only a short period of exposure to cardioplegia rather than the prolonged times commonly used in the operating room. The length of exposure is limited by the need to maintain viable myocytes. However, this model has been well accepted in the literature for its usefulness in providing insights into the mechanisms of cardioplegic injury. ${ }^{13,17}$

The comparison between normal rabbit atria and the atria from patients with coronary artery disease may not be valid because of underlying pathologic conditions in the human myocytes. However, because both species reacted to cardioplegia in a similar manner, it is unlikely that this had a major effect on our results. Moreover, none of these patients had a history of atrial arrhythmias or visible atrial pathology at the time of operation.

Clinical implications. The detrimental effects of edema on cardiac function have long been recognized, and previous attempts have been made to limit edema osmotically with improved cardioprotection as judged by better recovery of function, blood flow, and metabolic intermediates. ${ }^{6-8,15}$ However, this study emphasizes that the tonicity of the cardioplegic solution, rather than its osmolarity, is a more important factor in controlling myocardial edema during cardioplegia. Isosmotically replacing $\mathrm{Cl}^{-}$with a poorly permeant anion to lower the $\mathrm{KCl}$ product turned a hypotonic St. Thomas' Hospital solution into an isotonic solution and prevented myocyte swelling in the cold. Cardioplegic solutions designed in accord with Donnan equilibrium theory will need to be assessed in intact heart models to fully evaluate their clinical potential.

REFERENCES

1. Hearse DJ, Braimbridge MV, Jynge P. Protection of ischemic myocardium: cardioplegia. New York: Raven Press; 1981. 
2. Fremes SE, Weisel RD, Mickle DAG, Ivanov J, Madonik MM, Seawright SJ, et al. Myocardial metabolism and ventricular function following cold potassium cardioplegia. J Thorac Cardiovasc Surg 1987;89:531-46.

3. Engelman RM, Rousou JH, Lemeshow S, Dobbs WA. The metabolic consequences of blood and crystalloid cardioplegia. Circulation 1981;64(Suppl):II67-74.

4. Sunamori M, Harrison CE. Myocardial respiration and edema following hypothermic cardioplegia and anoxic arrest. J Thorac Cardiovasc Surg 1979;78:208-16.

5. Kay HR, Levine FH, Fallon JT, Grote GJ, Butchart EG, Rao $\mathrm{S}$, et al. Effect of cross-clamp time, temperature, and cardioplegic agents on myocardial function after induced arrest. J Thorac Cardiovasc Surg 1978;76:590-603.

6. Folgia RO, Steed DL, Follette DM, Deland E, Buckberg GD. Iatrogenic myocardial edema with potassium cardioplegia. J Thorac Cardiovasc Surg 1979;78:217-22.

7. Hsu DT, Weng ZC, Nicolosi AC, Detweiler PW, Sciacca R, Spotnitz HM. Quantitative effects of myocardial edema on the left ventricular pressure-volume relationship: influence of cardioplegia osmolarity over two hours of ischemic arrest. J Thorac Cardiovasc Surg 1993;106:651-7.

8. Wang ZC, Nicolosi AC, Detwiler PW, Hsu DT, Schierman SW, Goldstein AH, et al. Effects of crystalloid, blood, and University of Wisconsin perfusates on weight, water content, and left ventricular compliance in an edema-prone, isolated porcine heart model. J Thorac Cardiovasc Surg 1992;103:504-13.

9. Cohen NM, Allen CA, Belz MK, Nixon TE, Wise RM, Damiano RJ Jr. Electrophysiological consequences of hypothermic hyperkalemic elective cardiac arrest. J Card Surg 1993;8:156-60

10. Cohen NM, Allen CA, Hsia PW, Nixon TE, Wise RM, Damiano RJ Jr. Electrophysiological consequences of hyperkalemic cardioplegia during surgical ischemia. Ann Thorac Surg 1994;57:1076-83.

11. Yeh T Jr, Hanan SA, Johnson DE, Rebeyka IM, AbdElfattah AS, Lee KF, et al. Superior myocardial preservation with modified UW solution after prolonged ischemia in the rat heart. Ann Thorac Surg 1990;49:932-9.

12. Schaper J, Scheld HH, Schmidt U, Hehrlein F. Ultrastructural study comparing the efficacy of five different methods of intraoperative myocardial protection in the human heart. J Thorac Cardiovasc Surg 1986;92:47-55.

13. Handy JR Jr, Dorman BH, Cavallo MJ, Hinton RB, Roy RC, Crawford FA, et al. Direct effects of oxygenated crystalloid or blood cardioplegia on isolated myocyte contractile function. J Thorac Cardiovasc Surg 1996;112:1064-72.

14. Kloner RA, Ganote CE, Jennings RB. The "no reflow" phenomenon after temporary coronary occlusion in the dog. J Clin Invest 1974;54:1496-508.

15. Rubboli A, Sobotka PA, Euler DE. Effect of acute edema on left ventricular function and coronary vascular resistance in the isolated rat heart. Am J Physiol 1994;267:H1054-61.

16. Baumgarten CM, Feher JJ. Osmosis and the regulation of cell volume. In: Sperelakis N, editor. Cell physiology source book. New York: Academic Press; 1995. p. 180-210.

17. Drewnowska K, Clemo HF, Baumgarten CM. Prevention of myocardial intracellular edema induced by St. Thomas' Hospital cardioplegic solution. J Mol Cell Cardiol 1991;23:121521.

18. Spotnitz WD, Clark MB, Rosenblum HM, Lazar HL, Haasler GB, Collins RH, et al. Effect of cardiopulmonary bypass and global ischemia on human and canine left ventricular mass: evidence for interspecies differences. Surgery 1984;96:230-9.

19. Bustamante JO, Watanabe T, Murphy DA, McDonald TF. Isolation of single atrial and ventricular cells from the human heart. Can Med Assoc J 1982;126:791-3.

20. Escande D, Coulombe A, Faivre JF, Deroubaix E, Coraboeuf E. Two types of transient outward currents in adult human atrial cells. Am J Physiol 1987;252:H142-8.

21. Peeters GA, Sanguinetti MC, Eki Y, Konarzewska H, Renlund DG, Karwande SV, et al. Method for isolation of human ventricular myocytes from single endocardial and epicardial biopsies. Am J Physiol 1995;268:H1757-64.

22. Drewnowska K, Baumgarten CM. Regulation of cellular volume in rabbit ventricular myocytes: bumetanide, chlorothiazide and ouabain. Am J Physiol 1991;260:C122-31.

23. Clemo HF, Baumgarten CM. Atrial natriuretic factor decreases cell volume of rabbit atrial and ventricular myocytes. Am J Physiol 1991;260:C681-90.

24. Stinner B, Krohn E, Gebhard MM, Bretschneider HJ. Intracellular $\mathrm{pH}, \mathrm{Na}^{+}$- and $\mathrm{K}^{+}$-activities at the onset of St. Thomas' cardioplegia: a study with ionselective microelectrodes. Thorac Cardiovasc Surg 1988:36:247-53.

25. Pine MB, Bing OHL, Weintraub R, Abelmann WH. Dissociation of cell volume regulation and sodium-potassium exchange pump activity in dog myocardium in vivo. $\mathrm{J}$ Mol Cell Cardiol 1979;11:585-90.

26. Caille JP, Ruiz-Ceretti E, Schanne OF. Intracellular chloride activity in rabbit papillary muscle: effect of ouabain. Am J Physiol 1981;240:C183-8.

27. Schmiedl A, Haasis G, Schnabel PA, Gebhard NM, Richter J. Morphometric evaluation of the volume shifts between intra- and extra-cellular space before and during global ischemia. Anat Rec 1995;241:319-27.

28. Jennings RB, Reimer KA, Steenbergen C. Myocardial ischemia revisited: the osmolar load, membrane damage, and reperfusion. J Mol Cell Cardiol 1986;18:769-80.

29. Mankad PS, Chester AH, Yacoub MH. Role of potassium concentration in cardioplegic solutions in mediating endothelial damage. Ann Thorac Surg 1991;51:89-93. 